\title{
Promoter Methylation and BDNF and DAT1 Gene Expression Profiles in Patients with Drug Addiction
}

\author{
Dor Mohammad Kordi-Tamandani ${ }^{a} \quad$ Shahrad Tajoddini ${ }^{b}$ Farzaneh Salimi $^{a}$ \\ ${ }^{a}$ Department of Biology, University of Sistan and Baluchestan, Zahedan, and ${ }^{\mathrm{b}}$ Kerman Neuroscience Research \\ Center, Kerman University of Medical Sciences, Kerman, Iran
}

\section{Key Words}

Brain-derived neurotrophic factor - Dopamine transporter 1 . Expression · Gene · Methylation · Dopamine - Drug addiction

\begin{abstract}
Background: Drug addiction is a brain disorder that has negative consequences for individuals and society. Addictions are chronic relapsing diseases of the brain that are caused by direct drug-induced effects and persevering neuroadaptations at the epigenetic, neuropeptide and neurotransmitter levels. Because the dopaminergic system has a significant role in drug abuse, the purpose of this study was to analyze the methylation and expression profile of brain-derived neurotrophic factor (BDNF) and dopamine transporter (DAT1) genes in individuals with drug addiction. Materials and Methods: BDNF and DAT1 promoter methylation were investigated with a methylation-specific polymerase chain reaction (PCR) technique in blood samples from 75 individuals with drug addiction and 65 healthy controls. The expression levels of BDNF and DAT1 were assessed in 12 mRNA samples from the blood of patients and compared to the samples of healthy controls $(n=12)$ with real-time quantitative reverse transcription PCR. Results: No significant differences were found in the methylation of BDNF and DAT1 between patients and controls, but the relative levels of expression of
\end{abstract}

$B D N F$ and DAT1 mRNA differed significantly in the patients compared to controls $(p<0.0001)$. Conclusion: These results showed that the methylation status of the BDNF and DAT1 genes had no significant function in the processes of drug addiction.

(c) 2015 S. Karger AG, Basel

\section{Introduction}

Drug addiction is a chronic relapsing disorder that is characterized by compulsive drug seeking [1,2]. Mechanisms involving dopamine and endogenous opioids have been investigated in many addiction studies [3]. The dopaminergic system has an important role in the reinforcing effects of drug abuse $[4,5]$. The following 3 agents have been shown to be involved in the development of addiction: genetic, diverse environmental, and effects of drugs on gene expression or mRNA levels [6]. A recent study has shown that transcription factors, such as noncoding RNAs, histone modifications and chromatin structure, could change the transcriptional potential of genes. These transcription factors also contribute significantly to many neuroadaptations that result from chronic exposure to drugs [7]. Increasing evidence supports the hypothesis that every mechanism of epigenetic regulation

\section{KARGER 125}

(c) 2015 S. Karger AG, Base

$1015-2008 / 15 / 0822-0094 \$ 39.50 / 0$

E-Mail karger@karger.com

www.karger.com/pat
Dr. D.M. Kordi Tamandani

Department of Biology

University of Sistan and Baluchestan

PO Box 98155-987, Zahedan (Iran)

E-Mail dor_kordi @yahoo.com 
is directly affected by drugs of abuse and that these adaptations are among the main processes through which drugs induce the highly stable changes in the brain that mediate the addicted phenotype [8]. The important epigenetic mechanisms are DNA methylation, histone modifications and small noncoding RNAs [1,9]. The present study focused on examining epigenetic variations, such as DNA methylation, which is a covalent modification of DNA that involves the addition of a methyl group to cytosine residues in dinucleotide $\mathrm{CpG}$ sequences by DNA methyltransferases. This causes gene silencing by several mechanisms. One of these mechanisms is direct interference of the binding to DNA of specific transcription factors, such as AP-2, c-Myc/Myn, the cyclic AMP-dependent activator CREB, E2F and NF- $\kappa \mathrm{B}$, which recognize sequences containing $\mathrm{CpG}$ residues [10]. The CpG-rich regions overlap with the promoters of $50-60 \%$ of human genes and are usually methylated more than the CpG dinucleotides that are found outside of islands $[8,11]$.

In this study, we examined the effects of DNA methylation on the expression of brain-derived neurotrophic factor $(B D N F)$ and dopamine transporter (DAT1) genes. These genes are important in brain function. BDNF, which is a component of the nerve growth factor family, has an important role in the development of the central nervous system and in synaptic plasticity $[12,13]$. Increased BDNF expression initiates changes in synaptic strength and neuronal signaling. Signal transduction is initiated by the binding of BDNF to two different transmembrane receptors: the tyrosine kinase receptor $\mathrm{B}$ (Ntrk2 or TrkB) and the neurotrophin receptor. BDNF binding to TrkB triggers the ligand-dependent dimerization of the receptor, the autophosphorylation of specific intracellular tyrosine residues and the activation of 3 different signal transduction cascades, including phosphoinositide 3-kinase, mitogen-activated protein kinase/ extracellular signal-regulated kinase and phospholipase $\mathrm{C} \gamma$ cascades. Some of these intracellular transduction mechanisms can also be activated by the stimulation of dopamine and glutamate neurotransmission. Some evidence has shown that crosstalk between these pathways might potentiate synaptic plasticity in drug addiction [14]. BDNF protein promotes the survival of nerve cells (neurons) by playing a role in the growth, maturation (differentiation) and maintenance of these cells. In the brain, BDNF protein is active at the connections between nerve cells (synapses) where cell-to-cell communication occurs. The $B D N F$ gene is located in a region of chromosome $11 \mathrm{p} 13[13,15]$. The DAT1 gene, which is also identified as SLC6A3 [16], is located on chromosome 5p15
Table 1. Demographic data of patients and control group

\begin{tabular}{lccc}
\hline & $\begin{array}{c}\text { Patients } \\
(\mathrm{n}=75)\end{array}$ & $\begin{array}{l}\text { Controls } \\
(\mathrm{n}=64)\end{array}$ & $\begin{array}{l}\mathrm{p} \\
\text { value }\end{array}$ \\
\hline Sex & & & 0.051 \\
$\quad$ Male & 41 & 40 & \\
$\quad \begin{array}{l}\text { Female } \\
\text { Average age, years }\end{array}$ & 34 & 24 & \\
$\begin{array}{l}\text { Education level } \\
\quad \text { Less than diploma }\end{array}$ & 28.11 & 27.59 & $>0.50$ \\
$\quad$ More than diploma & 57 & 46 & - \\
$\quad$ Unknown & 6 & 10 & - \\
History of substance abuse & 13 & 8 & - \\
$\quad$ Less than 2 years & & & - \\
$\quad$ More than 2 years & 38 & - & - \\
\hline
\end{tabular}

and belongs to a family of $\mathrm{Na} / \mathrm{Cl}$-dependent transporters. This transporter is widely distributed throughout the brain in areas of dopaminergic activity. DAT is localized in the plasma membrane of axon terminals, and it reuptakes dopamine from the synapse [17] and controls the levels of dopamine in the extracellular space [18-20]. The goal of the present study was to investigate the effects of the promoter hypermethylation of $B D N F$ and $D A T$ and their expression profiles in individuals with drug addiction.

\section{Materials and Methods}

\section{Study Subjects}

The case-control study involved the collection of peripheral blood samples (2-4 ml) of 139 subjects (table 1). Seventy-five cases were newly diagnosed and untreated individuals with drug addiction [mean age \pm standard deviation (SD): $28.11 \pm 12.64$ years]. The samples were collected from the Bahonar and Afzalipour Hospitals in Kerman, Iran, during 2013. The Ethics Committee of the Bahonar and Afzalipour Hospitals approved this study. It is noteworthy that all used drugs by our cases were part of the opioid class. Our control groups have been selected from individuals without any history of any drug addiction or even drug abuse. Control peripheral blood samples ( $n=64$, mean age \pm SD: $27.59 \pm 8.45$ years $)$ were collected from the same hospitals in an age range similar to our case group.

\section{DNA Isolation, DNA Modification and Methylation-Specific} Polymerase Chain Reaction

Genomic DNA was extracted from ethylenediaminetetraacetic acid-anticoagulated peripheral blood samples with the salting-out method from patient and healthy control samples, and its quality was estimated with a spectrophotometer. DNA bisulfate modification was prepared with a Promega kit. The annealing temperatures 
Table 2. Primer sequences and annealing temperatures

\begin{tabular}{lllc}
\hline Genes & Sequences $\left(5^{\prime} \rightarrow 3^{\prime}\right)$ & Annealing temperature, ${ }^{\circ} \mathrm{C}$ & Product size \\
\hline DAT1 M & $\begin{array}{l}\text { F: TTTTTTTCGTTTAGTTGGGAGTC } \\
\text { R: GAAAACCTAAAAATCCGAAACGT }\end{array}$ & 51 & 162 \\
\hline DAT1 U & F: TTTTTTTTGTTTAGTTGGGAGTTGT & 58 & 162 \\
& R: CAAAAACCTAAAAATCCAAAACATC & & 192 \\
\hline BDNF M & F: GTTTTTGTGGGTAATTAGTGGTTC & 53 & 193 \\
& R: AATCTCCAACCGATAAAATCGTA & & 89 \\
\hline BDNF U & F: TTTTTGTGGGTAATTAGTGGTTTGT & 58 & 101 \\
\hline RAT1 (real time) & F: CTCTGCGAGGCGTCTGTT & 60 & \\
\hline RD : AGCTGGAGAAGGCGATCAG (real time) & F: TAACGGCGGCAGACAAAAAGA & 60 & \\
\hline & R: GAAGTATTGCTTCAGTTGGCCT & & \multirow{2}{*}{5} \\
\hline
\end{tabular}

$\mathrm{M}=$ Methylated; $\mathrm{U}=$ unmethylated $\mathrm{F}$ = forward $\mathrm{R}=$ reverse .

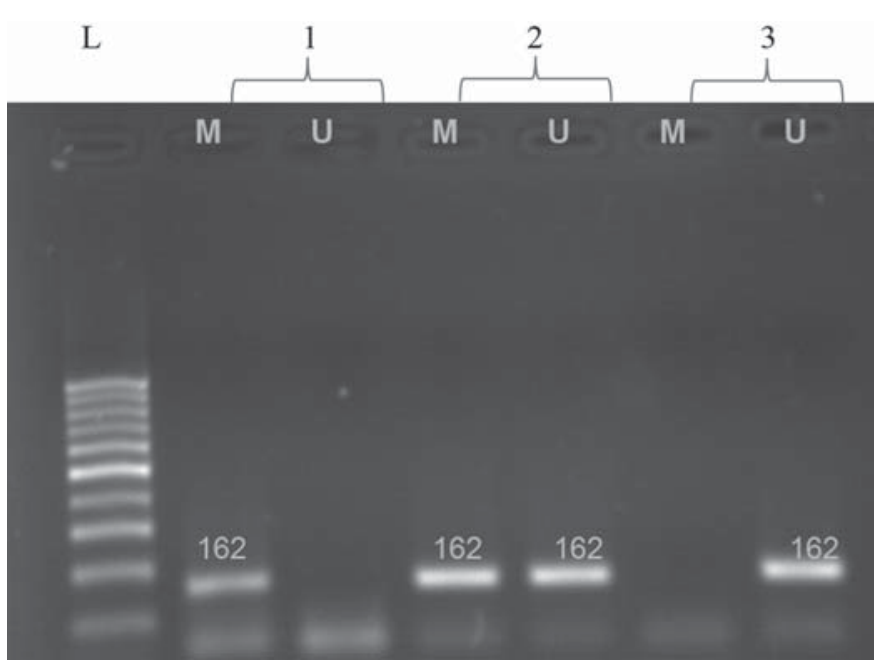

Fig. 1. Methylation analysis of the DAT gene. Lanes U and M: amplified products with primers recognize unmethylated (U) and methylated (M) sequences (162 bp); lane L: DNA ladder (100 bp).

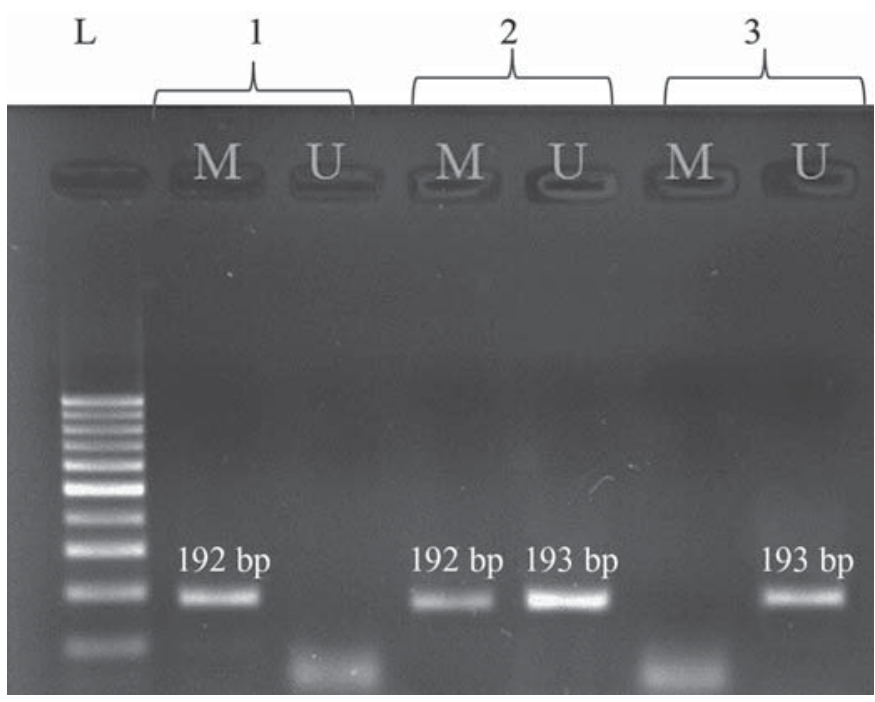

Fig. 2. Methylation analysis of the BDNF gene. Lane U: amplified product with primers recognizes unmethylated sequence (193 bp); lane M: amplified product with primers recognizes methylated sequence (192 bp); lane L: DNA ladder (100 bp).

annealing at a temperature of $53^{\circ} \mathrm{C}$ for $B D N F$ (methylated primer), $58^{\circ} \mathrm{C}$ for $B D N F$ (unmethylated primer), $51^{\circ} \mathrm{C}$ for DAT1 (methylated primer) and $58^{\circ} \mathrm{C}$ for $D A T 1$ (unmethylated primer) for $30 \mathrm{~s}$; extension at $72^{\circ} \mathrm{C}$ for $3 \mathrm{~s}$. The final incubation was completed at $72^{\circ} \mathrm{C}$ for $10 \mathrm{~min}$. Finally, $10 \mu \mathrm{l}$ of each PCR product was directly loaded into nondenaturing $2 \%$ agarose gels, stained with ethidium bromide and visualized under ultraviolet illumination (fig. 1, 2). 
Table 3. Methylation status of $D A T 1$ and $B D N F$ genes in individuals with drug addiction and healthy controls

\begin{tabular}{llrrlll}
\hline Genes & $\begin{array}{l}\text { Methylation Controls } \\
\text { status }\end{array}$ & & & & & \\
& & & & & \\
DAT1 & MM & 11 & 13 & 0.50 & 0.55 & $0.13-2.14$ \\
& MU & 45 & 47 & 0.22 & 0.48 & $0.15-2.14$ \\
& UU & 8 & 15 & Ref. & - & - \\
\hline BDNF & MM & 12 & 8 & 0.28 & 0.45 & $0.12-1.63$ \\
& MU & 39 & 48 & 0.84 & 0.84 & $0.33-2.06$ \\
& UU & 13 & 19 & Ref. & - & - \\
\hline
\end{tabular}

$\mathrm{OR}=$ Odds ratio; $\mathrm{CI}=$ confidence interval; $\mathrm{M}$ = methylated; $\mathrm{U}=$ unmethylated.

Extraction of RNA and Reverse Transcription PCR

First, the buffy coat fraction of blood was separated, and the total RNA was then extracted from blood with a Pars Tous Total RNA Extraction Kit. The RNA concentration was identified spectrophotometrically, and the quality of all of the samples was confirmed by electrophoresis in ethidium bromide-stained 1\% agarose gel. One milligram of total RNA was converted to cDNA with a Vivantis cDNA synthesis kit according to the manufacturer's instructions.

\section{Quantitative Real-Time PCR with SYBR Green}

Real-time PCR of BDNF and DAT1 was performed in order to examine the quantitative association between the PCR products that were obtained from the target gene and a housekeeping gene (RNA18s). Quantitative reverse transcription PCR assays were performed using the reverse transcription PCR System (Applied Biosystems) with SYBR green fluorescence. PCR amplification was done in $20 \mu \mathrm{l}$ of the reaction mixture containing $10 \mu \mathrm{l}$ of $2 \times$ SYBR green, $2 \mu \mathrm{l}$ of primers (forward and reverse), $2 \mu \mathrm{l}$ of cDNA and $6 \mu \mathrm{l}$ of $\mathrm{H}_{2} \mathrm{O}$.

The data analysis was performed with SPSS software version 19.0 , and t tests were used to evaluate the association between the methylation status of the $B D N F$ and $D A T 1$ genes and the clinical parameters [target cycle threshold $\left(\mathrm{C}_{\mathrm{T}}\right)$ /housekeeper $\mathrm{C}_{\mathrm{T}}$ ]. For all of the tests, the level of significance was set at $\mathrm{p}<0.0001$.

\section{Results}

\section{Detection of Methylation with MS-PCR}

Methylation was detected in the BDNF and DAT1 promoter genes with MS-PCR. As shown in table 3, there were no significant differences in the methylation percentages of both genes between the patients and controls. Methylation of $B D N F$ was found in $75 \%$ (56 out of 75 ) of the patients with drug addiction and in $79.68 \%$ (51 out of 64 ) of the healthy controls. Similarly, DAT1 gene methylation
Table 4. Comparison of relative gene expression for DAT1 and $B D N F$ between patients with drug addiction and healthy controls

\begin{tabular}{llllll}
\hline Genes & & $\mathrm{n}$ & Mean $\pm \mathrm{SD}$ & Range & p value \\
\hline DAT1 & cases & 12 & $1.20 \pm 0.23$ & $0.77 \pm 0.35$ & 0.0001 \\
& controls & 12 & $1.77 \pm 0.25$ & & \\
\hline BDNF & cases & 12 & $1.27 \pm 0.28$ & $0.87 \pm 0.39$ & 0.0001 \\
& controls & 12 & $1.91 \pm 0.27$ & & \\
\hline
\end{tabular}

was found in $80 \%$ ( 60 out of 75 ) of the patients and $87.5 \%$ (56 out of 64) of the controls. These differences were not statistically significant between the patients and healthy individuals in comparison to the unmethylated pattern.

\section{Gene Expression Analysis}

The analysis of relative gene expression (target $\mathrm{C}_{\mathrm{T}}$ / housekeeper $\mathrm{C}_{\mathrm{T}}$ ) for $B D N F$ and $D A T 1$ was done by normalizing the target $C_{T}$ to housekeeping $C_{T}$ genes. As shown in table 4 , there was a significant difference between the patients and healthy controls in a Mann-Whitney test $(\mathrm{p}<0.0001)$.

\section{Discussion}

Our results showed that the promoter methylation variations of the $B D N F$ and $D A T 1$ genes were not significantly different between patients with drug addiction and healthy controls.

A number of studies have focused on the opioidergic and dopaminergic mechanisms of addiction [3]. Drug abuse plays an essential role in drug reward and reinforcement by activating the mesolimbic dopaminergic pathway [21]. Novel data have detected that genes that encode molecules that are involved in the dopaminergic system (dopamine receptors, transporter and enzymes) are linked to drug addiction. The methylation status of the promoters of some of these genes have been implicated in substance addiction, but this analysis was not performed for the dopamine transporter gene [22].

$\mathrm{BDNF}$ is an important regulator of the mesolimbic dopamine pathway, and this neurotrophic factor is expressed at high levels by dopaminergic neurons [23-25]. $\mathrm{BDNF}$ is a critical regulator of drug dependency. Certain studies in drug addiction, schizophrenia and Parkinson's disease have shown that BDNF regulates the expression of the dopamine $\mathrm{D}_{3}$ receptor $[26,27]$. 
Studies of the DNA methylation profiles of the CpG island of the BDNF gene have shown that this gene could be useful as a biomarker of major depression $[13,28]$. The $B D N F$ gene has been implicated as a susceptible locus for addiction to multiple drugs of abuse, such as alcohol. In addition, a small nucleotide polymorphism in this gene has been linked with an early onset of alcoholism [29]. The results of a study by Lubin et al. [30] have shown that DNA methyltransferase enzyme inhibition causes BDNF DNA demethylation, which leads to increased BDNF mRNA levels in the hippocampus in vivo.

DAT1 has a crucial function in the regulation of dopamine neurotransmission by drawing dopamine back into the presynaptic neurons and terminating its action. This transporter is encoded by the SLC6A3 gene $[13,31]$. Recent studies have indicated that epigenetic mechanisms are directly involved in the molecular mechanisms that influence the genetic events that are involved in development as well as in the heritability of addiction to drugs of abuse [32, 33].

Zhou et al. [34] have shown that drugs and alcohol are able to change the expression of genes through modifications of histone complexes in the human hippocampus.
Liu et al. [35] have also indicated that epigenetic mechanisms can inhibit genes, such as prolactin, through the activation of the dopamine $\mathrm{D}_{2}$ receptor, which results in histone deacetylation. Frieling et al. [36] have observed hypermethylation of the dopamine $\mathrm{D}_{2}$ receptor promoter in blood cells in individuals with drug addiction compared to healthy controls.

This study found no significant differences in the methylation of the BDNF and DAT1 gene promoters in these two groups. Nevertheless, there were remarkable differences in the expression of the BDNF and DAT1 genes in patients with drug addiction. These findings suggest that further investigation of other epigenetic agents are needed to highlight the exact reason underlying the change in gene expression.

\section{Acknowledgments}

We thank the Institute of Neuroscience, Kerman University of Medical Sciences, Kerman, and the Department of Biology, University of Sistan and Baluchestan, Zahedan, Iran, for supporting this project financially.

\section{References}

1 Vassoler FM, Sadri-Vakili G: Mechanisms of transgenerational inheritance of addictivelike behaviors. Neuroscience 2014;264:198206.

2 Cami J, Farre M: Drug addiction. N Engl J Med 2003;349:975-986.

-3 Tzschentke TM, Schmidt WJ: Glutamatergic mechanisms in addiction. Mol Psychiatry 2003;8:373-382.

4 Justinova Z, Panlilio LV, Goldberg SR: Drug addiction. Curr Top Behav Neurosci 2009;1: 309-346.

5 Volkow ND, et al: Dopamine in drug abuse and addiction: results from imaging studies and treatment implications. Mol Psychiatry 2004;9:557-569.

6 Kreek MJ, Nielsen DA, LaForge KS: Genes associated with addiction: alcoholism, opiate, and cocaine addiction. Neuromol Med 2004; 5:85-108.

7 Nestler EJ: Molecular basis of long-term plasticity underlying addiction. Nat Rev Neurosci 2001;2:119-128.

8 Robison AJ, Nestler EJ: Transcriptional and epigenetic mechanisms of addiction. Nat Rev Neurosci 2011;12:623-637.

$\checkmark 9$ Waddington $\mathrm{CH}$ : The epigenotype. 1942. Int J Epidemiol 2012;41:10-13.

10 Das PM, Singal R: DNA methylation and cancer. J Clin Oncol 2004;22:4632-4642.
11 Wang Y, Leung FC: An evaluation of new criteria for $\mathrm{CpG}$ islands in the human genome as gene markers. Bioinformatics 2004;20:11701177 .

12 Fumagalli F, et al: BDNF gene expression is reduced in the frontal cortex of dopamine transporter knockout mice. Mol Psychiatry 2003;8:898-899.

13 Kordi-Tamandani DM, Sahranavard R, Torkamanzehi A: DNA methylation and expression profiles of the brain-derived neurotrophic factor (BDNF) and dopamine transporter (DAT1) genes in patients with schizophrenia. Mol Biol Rep 2012;39:10889-10893.

14 Corominas M, Roncero C, Ribases M, Castells $\mathrm{X}$, Casas M: Brain-derived neurotrophic factor (BDNF) and its intracellular signaling pathways in cocaine addiction. Neuropsychobiology 2007;55:2-13.

15 Egan MF, et al: The BDNF Val66Met polymorphism affects activity-dependent secretion of BDNF and human memory and hippocampal function. Cell 2003;112:257-269.

-16 Sullivan D, et al: Dopamine transporter DAT and receptor DRD2 variants affect risk of lethal cocaine abuse: a gene-gene-environment interaction. Transl Psychiatry 2013;3:e222.

17 Merchant BA, Madura JD: Insights from molecular dynamics: the binding site of cocaine in the dopamine transporter and permeation pathways of substrates in the leucine and dopamine transporters. J Mol Graph Model 2012;38:1-12.

18 Norregaard L, Gether U: The monoamine neurotransmitter transporters: structure, conformational changes and molecular gating. Curr Opin Drug Discov Devel 2001;4: 591-601.

19 Khodayari N, et al: Association of the dopamine transporter gene (DAT1) core promoter polymorphism -67T variant with schizophrenia. Am J Med Genet B Neuropsychiatr Genet 2004;129B:10-12.

20 Zhang H, et al: Regulation of dopamine transporter activity by carboxypeptidase $\mathrm{E}$. Mol Brain 2009;2:10.

21 Di Chiara G, Bassareo V: Reward system and addiction: what dopamine does and doesn't do. Curr Opin Pharmacol 2007;7:69-76.

22 Gorwood P, et al: Genetics of dopamine receptors and drug addiction. Hum Genet 2012; 131:803-822.

23 Berton O, et al: Essential role of BDNF in the mesolimbic dopamine pathway in social defeat stress. Science 2006;311:864-868.

24 Seroogy KB, et al: Dopaminergic neurons in rat ventral midbrain express brain-derived neurotrophic factor and neurotrophin-3 mRNAs. J Comp Neurol 1994;342:321-334. 
25 Baquet ZC, Bickford PC, Jones KR: Brain-derived neurotrophic factor is required for the establishment of the proper number of dopaminergic neurons in the substantia nigra pars compacta. J Neurosci 2005;25:6251-6259.

26 Fisch GS: Animal models and human neuropsychiatric disorders. Behav Genet 2007;37: $1-10$.

27 Kalueff AV, et al: Domain interplay concept in animal models of neuropsychiatric disorders: a new strategy for high-throughput neurophenotyping research. Behav Brain Res 2008; 188:243-249.

28 Song Y, Miyaki K, Suzuki T, Sasaki Y, Tsutsumi A, Kawakami N, Shimazu A, Takahashi M, Inoue A, Kan C, Kurioka S, Shimbo T: Altered DNA methylation status of human brain-derived neurotrophic factor gene could be useful as biomarker of depression. Am J Med Genet B Neuropsychiatr Genet 2014;4:357-364.
29 Jeanblanc J, He DY, Carnicella S, Kharazia V, Janak PH, Ron D: Endogenous BDNF in the dorsolateral striatum gates alcohol drinking. J Neurosci 2009;29:13494-13502.

30 Lubin FD, Roth TL, Sweatt JD: Epigenetic regulation of BDNF gene transcription in the consolidation of fear memory. J Neurosci 2008;28:10576-10586.

31 O'Loughlin J, et al: Genetically decreased CYP2A6 and the risk of tobacco dependence: a prospective study of novice smokers. Tob Control 2004; 13:422-428.

32 Renthal W, Nestler EJ: Epigenetic mechanisms in drug addiction. Trends Mol Med 2008:14:341-350.
Russo SJ, et al: The addicted synapse: mechanisms of synaptic and structural plasticity in nucleus accumbens. Trends Neurosci 2010; 33:267-276.

34 Zhou Z, et al: Substance-specific and shared transcription and epigenetic changes in the human hippocampus chronically exposed to cocaine and alcohol. Proc Natl Acad Sci USA 2011;108:6626-6631.

35 Liu JC, et al: Epigenetic mechanisms in the dopamine $\mathrm{D}_{2}$ receptor-dependent inhibition of the prolactin gene. Mol Endocrinol 2005; 19:1904-1917.

36 Frieling H, et al: Epigenetic dysregulation of dopaminergic genes in eating disorders. Int J Eat Disord 2010;43:577-583. 